\title{
Computer-guided discovery of epigenetics drugs: molecular modeling and identification of inhibitors of DNMT1
}

\author{
Jakyung Yoo*, José L Medina-Franco \\ From 7th German Conference on Chemoinformatics: 25 CIC-Workshop \\ Goslar, Germany. 6-8 November 2011
}

DNA methylation is a covalent chemical modification of DNA catalyzed by DNA methyltransferases (DNMTs) and plays a crucial role in epigenetic modifications. Inhibition of DNMT is a promising strategy for the treatment of various developmental and proliferative diseases, particularly cancers. Molecular docking and other computational approaches are increasingly being used to explore the ligand-binding interactions of DNMT inhibitors $[1,2]$. In this work we conducted molecular docking of experimentally known active compounds in the catalytic site of the recently published crystal structure of DNMT1 [3]. Prior docking, the conformation of the catalytic site was modelled with molecular dynamics into an active conformation. To our knowledge, this is the first molecular modelling study conducted with the catalytic binding site of this crystal structure. Based on the docking results, we developed a structure-based pharmacophore model. Molecular modelling results were compared with the insights previously obtained with a homology model of the methyltransferase domain of DNMT1 [4]. We also discuss the experimental inhibitory activity and docking of a novel DNMT1 inhibitor recently identified in our group [5]. Results of this work have direct implications in the future computer-based screening and optimization of inhibitors of DNMT1 and show that computational approaches form part of multidisciplinary efforts to further advance epigenetic therapies [1].

Published: 1 May 2012

Torrey Pines Institute for Molecular Studies, Port St. Lucie, Florida, 34987, USA
References

1. Medina-Franco JL, Caulfield T: Advances in the Computational Development of DNA Methyltransferase Inhibitors. Drug Discovery Today 2011, 16:418-425.

2. Kuck D, Caulfield T, Lyko F, Medina-Franco JL: Nanaomycin A Selectively Inhibits DNMT3B and Reactivates Silenced Tumor Suppressor Genes in Human Cancer Cells. Mol Cancer Ther 2010, 9:3015-3023.

3. Song J, Rechkoblit O, Bestor TH, Patel DJ: Structure of DNMT1-DNA Complex Reveals a Role for Autoinhibition in Maintenance DNA Methylation. Science 2011, 331:1036-1040.

4. Yoo J, Medina-Franco JL: Homology Modeling, Docking, and Structurebased Pharmacophore of Inhibitors of DNA Methyltransferase. J CompAided Mol Des 2011, 25:555-567.

5. Yoo J, Medina-Franco JL: Trimethylaurintricarboxylic Acid Inhibits Human DNA Methyltransferase 1: Insights from Enzymatic and Molecular Modeling Studies. J Mol Model, doi:10.1007/s00894-011-1191-4.

\section{doi:10.1186/1758-2946-4-S1-P25}

Cite this article as: Yoo and Medina-Franco: Computer-guided discovery of epigenetics drugs: molecular modeling and identification of inhibitors of DNMT1. Journal of Cheminformatics 2012 4(Suppl 1):P25.

\section{Publish with ChemistryCentral and every scientist can read your work free of charge \\ "Open access provides opportunities to our colleagues in other parts of the globe, by allowing anyone to view the content free of charge." \\ W. Jeffery Hurst, The Hershey Company. \\ - available free of charge to the entire scientific community \\ - peer reviewed and published immediately upon acceptance \\ - cited in PubMed and archived on PubMed Central \\ - yours - you keep the copyright \\ Submit your manuscript here: \\ http://www.chemistrycentral.com/manuscript/ \\ Chemistry Central}

